\title{
PEMANFAATAN APLIKASI SMS INFO UNTUK KEMUDAHAN PENYEBARAN INFORMASI DAN PENINGKATAN LAYANAN KEPADA MASYARAKAT DESA GONDANGMANIS BAE KUDUS
}

\author{
Tri Listyorini \\ Fakultas Teknik, Program Studi Teknik Informatika \\ Universitas Muria Kudus \\ Email: trilistyorini@umk.ac.id \\ Syafiul Muzid \\ Fakultas Teknik, Program Studi Sistem Informasi \\ Universitas Muria Kudus \\ Email: syafiul.muzid@umk.ac.id
}

\begin{abstract}
ABSTRAK
Perkembangan teknologi sekarang ini berubah menjadi era digital, salah satunya adalah teknologi SMS (Short Message Service). Teknologi SMS (Short Message Service) adalah sebuah teknologi yang berkembang seiring dengan adanya ponsel atau telepon seluler. Desa Gondangmanis terletak di Kecamatan Bae Kabupaten Kudus. Desa Gondangmanis adalah sebuah desa yang memiliki jumlah warga lebih dari 8000 orang. Teknologi informasi yang telah dikembangkan sangat membantu dalam penyebaran informasi dan peningkatan layanan kepada masyarakat. Masyarakat dan perangkat Desa Gondangmanis menginginkan sebuah cara untuk dapat menyampaikan dan menerima keluhan, kritik, saran serta pendapat secara cepat dan mudah tanpa harus ke balai desa. Dari situasi diatas kami bermaksud untuk mengembangkan sebuah aplikasi komputer yang dapat digunakan untuk membantu perangkat dan masyarakat Desa Gondangmanis dalam menyebarkan informasi dan menyampaikan keluhan, kritik dan saran untuk perkembangan desa, serta melakukan pelatihan penggunaan aplikasi tersebut bagi para perangkat Desa Gondangmanis. Metode dalam pemecahan kerangka permasalahan yang diambil meliputi analisa, pengadaaan bahan alat, pembuatan rancangan, pelatihan dan sosialisasi. Dengan metode tersebut menghasilkan sebuah aplikasi SMS info yang berguna bagi masyarakat gondang manis dalam penyebaran informasi dan peningkatan layanan kepada masyarakat.
\end{abstract}

Kata kunci: SMS gateway, teknologi, informasi.

\section{ABSTRACT}

Technological developments now turned into the digital, one of which is a technology SMS (Short Message Service). Technology SMS (Short Message Service) is a technology that has developed along with their phone or mobile phone. The village is located in the district Gondangmanis Bae Kudus. Gondangmanis village is a village that has a number of residents of more than 8000 people. Information technology has developed greatly assist in the dissemination of information and improved service to the public. Community and Rural device Gondangmanis want a way to be able to deliver and receive complaints, criticisms, suggestions and opinions quickly and easily without having to village hall. From the above situation, we aim to develop a computer application that can be used to help the device and Gondangmanis village communities to disseminate information and submit complaints, criticisms and suggestions for the development of the village, as well as training for the use of the application device Gondangmanis village. Method in the Framework of solving problems taken include analysis, providing tools materials, drafting, training and socializing. With this method generates an SMS application info that is useful for society gondang sweet in information dissemination and improved service to the public.

Keywords: SMS gateway, technology, information.

\section{PENDAHULUAN}

Teknologi SMS (Short Message Service) adalah sebuah teknologi yang berkembang seiring dengan adanya ponsel atau telepon seluler. Teknologi SMS adalah sebuah teknologi pengiriman data dari sebuah ponsel ke ponsel lain dalam bentuk data yang kemudian diconvert menjadi teks untuk dapat ditampilkan dan digunakan oleh pengguna.

Desa Gondangmanis terletak di Kecamatan Bae Kabupaten Kudus. Desa Gondangmanis adalah sebuah desa yang memiliki jumlah warga lebih dari 8000 orang. Desa Gondangmanis merupakan desa 
yang memiliki lokasi strategis untuk mudah diakses dari pusat kota Kabupaten Kudus. Bahkan beberapa perusahaan kretek besar seperti PT Djarum memilih Desa Gondangmanis sebagai lokasi pabrik utama.

Dalam pemanfaatan teknologi informasi, Desa Gondangmanis cukup maju dibandingkan dengan desa-desa lainnya di Kabupaten Kudus. Desa Gondangmanis telah memiliki forum online serta diskusi online di media sosial. Teknologi informasi yang telah dikembangkan sangat membantu dalam penyebaran informasi dan peningkatan layanan kepada masyarakat. Namun tidak semua warga Desa Gondangmanis dapat menggunakan internet dengan baik dan memiliki koneksi internet. Sehingga terkadang informasi yang disampaikan tidak tersebar dengan baik.

Hal ini menjadi sebuah masalah bagi perangkat Desa Gondangmanis dalam hal penyebaran informasi dengan cepat dan tepat sasaran. Sehingga dibutuhkan suatu cara untuk memudahkan penyebaran informasi kepada seluruh masyarakat Desa Gondangmanis. Pada saat diskusi pemerintah desa muncul sebuah gagasan tentang penggunaan teknologi SMS Gateway untuk media penyebaran informasi tersebut. Ide ini muncul dikarenakan hampir semua warga Desa Gondangmanis telah memiliki handphone. Berdasarkan survei hampir 95\% warga Desa Gondangmanis telah memiliki telepon seluler (handphone) dan bisa menggunakan dengan baik. Sehingga akan memudahkan jika ada sebuah sistem informasi berbasis SMS Gateway yang dapat digunakan dalam penyebaran informasi dari desa kepada warganya. SMS Gateway ini akan digunakan sebagai media informasi terkait kegiatan-kegiatan, undangan ke satu warga atau sekelompok warga. Selain itu, SMS Gateway juga dapat digunakan untuk menyampaikan dan menerima keluhan, kritik, saran serta pendapat dari warga kepada pemerintah desa secara cepat dan mudah tanpa harus ke balai desa.

Berangkat dari situasi ini, Universitas Muria Kudus yang memiliki beberapa program studi terkait teknologi informasi merasa terpanggil untuk ikut berperan serta dalam pengembangan keilmuan dan pengabdian kepada masyarakat khususnya dalam bidang teknologi informasi. Dari situasi diatas kami bermaksud untuk mengembangkan sebuah aplikasi komputer yang dapat digunakan untuk membantu perangkat dan masyarakat Desa Gondangmanis dalam menyebarkan informasi dan menyampaikan keluhan, kritik dan saran untuk perkembangan desa, serta melakukan pelatihan penggunaan aplikasi tersebut bagi para perangkat Desa Gondangmanis.

\section{PERUMUSAN MASALAH}

Berdasarkan situasi diatas maka dapat didentifikasi masalah yang sedang dihadapi dan dirumuskan adalah merancang dan membangun suatu sistem informasi berbasis SMS Gateway yang dapat membantu pemerintah Desa Gondangmanis dalam penyebaran informasi kepada warga desa serta dapat digunakan sebagai media penyampain kritik, saran dan pendapat dari warga kepada pemerintah desa.

\section{TUJUAN PENELITIAN}

Tujuan pengabdian ini adalah sebagai berikut : (1) Menghasilkan aplikasi SMS Info untuk memudahkan perangkat Desa Gondangmanis dalam menyebarkan informasi kepada masyarakat, (2) Memudahkan masyarakat desa untuk menyampaikan informasi, keluhan, kritik dan saran untuk pemerintah Desa Gondangmanis, (3) memberikan pengetahuan dan pengalaman kepada masuarakat Desa Gondangmanis terkait pemanfaatan teknologi SMS untuk kepentingan bermasyarakat secara baik dan benar.

\section{METODOLOGI PENELITIAN}

\subsection{Kerangka Pemecahan Masalah}

Berdasarkan masalah yang telah diuraikan dibutuhkan kerangka dalam memecahkan masalah sebagai berikut:

a. Analisa masalah dan kebutuhan terkait pemanfaatan sistem informasi SMS Gateway

b. Pengadaan bahan dan kebutuhan meliputi perangkat keras yang dibutuhkan dan pendataan nomor handphone warga,

c. Pembuatan rancangan dan pengembangan aplikasi SMS Info serta pengujian sistem,

d. Pelatihan kepada operator atau perangkat Desa Gondangmanis di Balai Desa Gondangmanis,

e. Sosialisasi dan pelatihan kepada masyarakat Desa Gondangmanis di Balai Desa Gondangmanis. 


\subsection{Realisasi Pemecahan Masalah}

Diharapkan setelah program pengabdian ini para perangkat Desa Gondangmanis dapat meningkatkan layanan kepada masyarakat desa, serta mampu memanfaatkan aplikasi SMS Info untuk menyebarkan informasi dengan cepat kepada masyarakat. Selain itu dengan adanya aplikasi SMS Info dan pelatihan pemanfaatannya, diharapkan masyarakat Desa Gondangmanis dapat memanfaatkan aplikasi SMS Info sebagai media untuk penyampaian pendapat, keluhan, kritik dan saran kepada pemerintah Desa Gondangmanis.

Pengabdian ini dilakukan oleh dosen Fakultas Teknik Universitas Muria Kudus dengan warga Desa Gondangmanis untuk penerapan intelektual dosen dalam pemanfaatan komputer untuk kebutuhan masyarakat melalui sistem informasi SMS Gateway Sistem informasi SMS Gateway adalah suatu sistem informasi yang dikembangkan dengan memanfaatkan integrasi antara komputer dengan perangkat modem untuk melakukan pengelolaan SMS.

\subsection{Khalayak Sasaran Antara Yang Strategis}

Sasaran dalam kegiatan pengabdian kepada masyarat adalah para perangkat Desa Gondangmanis, kelompok warga meliputi kelompok tani, kelompok pedagang, karang taruna, dan beberapa kelompok warga lainnya serta warga Desa Gondangmanis agar mereka dapat memanfaatkan aplikasi SMS Info untuk meningkatkan pelayanan kepada masyarakat dan memudahkan dan mempercepat penyampaian informasi, pendapat, kritik dan saran. Adapun jumlah sasaran yang akan dikenakan adalah (1) Pemerintah desa meliputi 14 perangkat Desa Gondangmanis dan 10 perwakilan Ketua RW dan RT, dan (2) 5 orang perwakilan kelompok warga (Tani, Pedagang, Pemuda). Selain pelaksanaan kegiatan tersebut, kegiatan pengabdian ini memiliki luaran sebagai berikut:

a. Publikasi dalam bentuk jurnal atau prosiding

b. Prototype sistem informasi berbasis SMS Gateway sebagai media penyebaran informasi terintegrasi

c. Bahan ajar terkait implementasi sistem informasi terhadap pengelolaam pemerintahan yang baik serta tanggap dan cepat terhadap informasi.

\subsection{Metode Kegiatan}

Kegiatan pada pengabdian kepada masyarakat ini meliputi:

a. Pelatihan penggunaan aplikasi SMS Info kepada perangkat Desa Gondangmanis untuk memudahkan penyebaran informasi sekitar 20 orang perangkat desa di Balai Desa.

b. Sosialisasi dan pelatihan untuk masyarakat Desa Gondangmanis di Balai Desa terkait pemanfaatan aplikasi SMS Info untuk memudahkan penyampaian pendapat, keluhan, kritik dan saran.

\subsection{Kerangka Pikir}

Dalam pengabdian masyarakat ini diharapkan dapat menunjang Menghasilkan aplikasi SMS Info untuk memudahkan perangkat Desa Gondangmanis dalam menyebarkan informasi kepada masyarakat, antara lain berisi materi:

a. Analisa kebutuhan data dan informasi

b. Pengadaan bahan dan peralatan meliputi: modem GSM Wavecom 420, Kartu Perdana GSM

c. Pendataan Nomor Handphone Warga dan Perangkat Desa Gondangmanis

d. Analisa dan Desain Sistem SMS

e. Pengembangan Sistem SMS dengan PHP

f. Pengujian Sistem SMS dan Koneksi Modem dan Integrasi Modul Sistem

g. Instalasi Sistem SMS di Balai Desa Gondangmanis

h. Pelatihan Perangkat Desa untuk menggunakan Aplikasi SMS

i. Sosialisasi penggunaan Aplikasi SMS untuk masyarakat Desa Gondangmanis

\section{PENELITIAN TERKAIT}

SMS Gateway adalah sebuah perangkat yang menawarkan layanan transit SMS, mentransformasikan pesan ke jaringan selular dari media lain, atau sebaliknya, sehingga memungkinkan pengiriman atau penerimaan pesan SMS dengan atau tanpa menggunakan ponsel. Sebuah sistem SMS 
Gateway, umumnya terdiri komponen Hardware (Server/Komputer yang dilengkapi dengan perangkat jaringan) dan Software (Aplikasi yang digunakan untuk pengolahan pesan). Dan untuk sebuah sistem yang besar umumnya menggunakan Database untuk penyimpanan data [1].

Menurut Alexander Setiawan (2006) tentang perancangan dan pembuatan sistem layanan SMS untuk Biro Adminstrasi Akademik Universitas Kristen Petra. Pada penelitian ini dijelaskan bahwa SMS Gateway dapat digunakan pada keperluan administrasi akademik [2]

Menurut Wahyu Pujiono, dkk (2009) dalam penelitian yang berjudul Aplikasi Mobile SMS Gateway Over GPRS Untuk Mengakses Sistem Informasi. Penelitian ini menjelaskan tentang pemanfaatan SMS Gateway sebagai sebuah cara untuk mengakses sistem informasi yang sudah diterapkan menggunakan mobile. Dengan memanfaatkan SMS Gateway akan memudahkan dalam akses terhadapa informasi pada sistem yang sudah ada [3].

Menurut Joko Triyono (2010) pada penelitian tentang pelayanan KRS On-Line berbasis SMS, SMS Gateway dapat dikembangkan untuk penyebaran informasi yang lebih cepat, tepat dan efisien. Pada penelitian tersebut sudah dihasilkan sebuah cara penyebaran sistem informasi KRS secara on-line, tetapi masih bersifat umum. Informasi hanya baru tentang waktu, KRS dan jadwal KRS [4].

SMS Gateway untuk Peningkatan Penjualan Tiket Berdasarkan Framework COBIT yang diangkat oleh Rizkysari dan Tri Listyorini pada tahun 2012 membahas mengenai pelayanan sms otomatis yang dilakukan oleh museum kretek untuk penjualan tiket wisata. Hal ini dilakukan untuk meningkatkan penjualan tiket pada museum kretek [5].

Pada pengabdian ini diharapkan dengan adanya sebuah aplikasi SMS Info yang dikembangkan akan membantu pemerintah Desa Gondangmanis dalam penyebaran informasi dan memudahkan warga masyarakat Desa Gondangmanis dalam menyampaikan pendapat, kritik dan saran

\section{HASIL DAN PEMBAHASAN}

Pada kegiatan ini menghasilkan sebuah aplikasi yang dapat dipergunakan oleh desa gondangmanis dalam memberikan informasi secara online. Berikut merupakan hasil dari aplikasi SMS Info.

a. Halaman Login

Halaman pada gambar 1 digunakan untuk memasuki sistem. Pengguna harus mengisi username dan pasword untuk dapat memasuki sistem. Pengguna dapat meminta username dan password ke Admin Sistem.

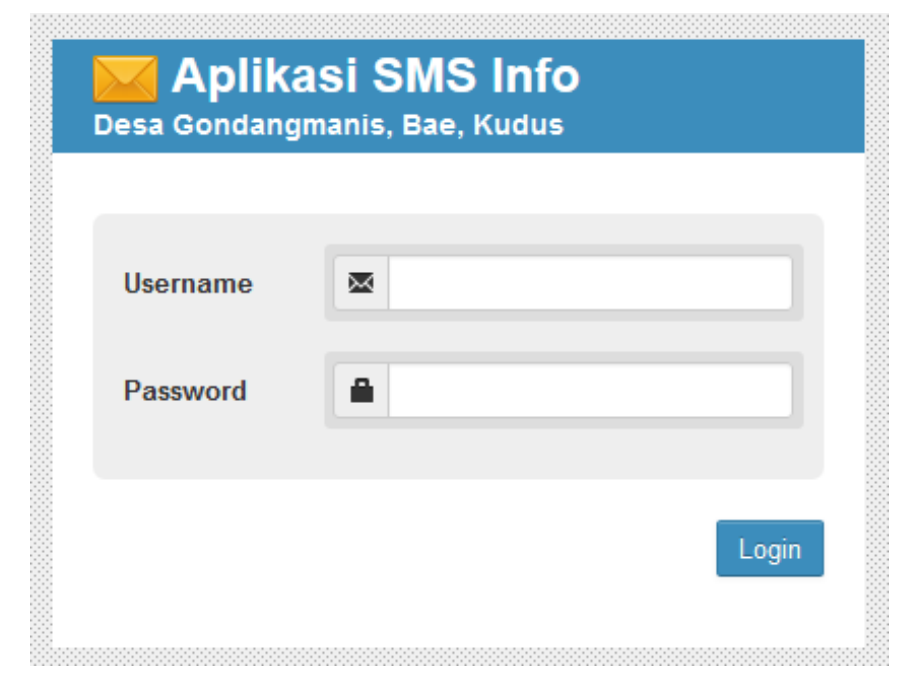

Gambar 1. Halaman Login

b. Halaman Selamat Datang (Beranda)

Halaman pada gambar 2 adalah tampilan awal saat pengguna telah berhasil melakukan login. 


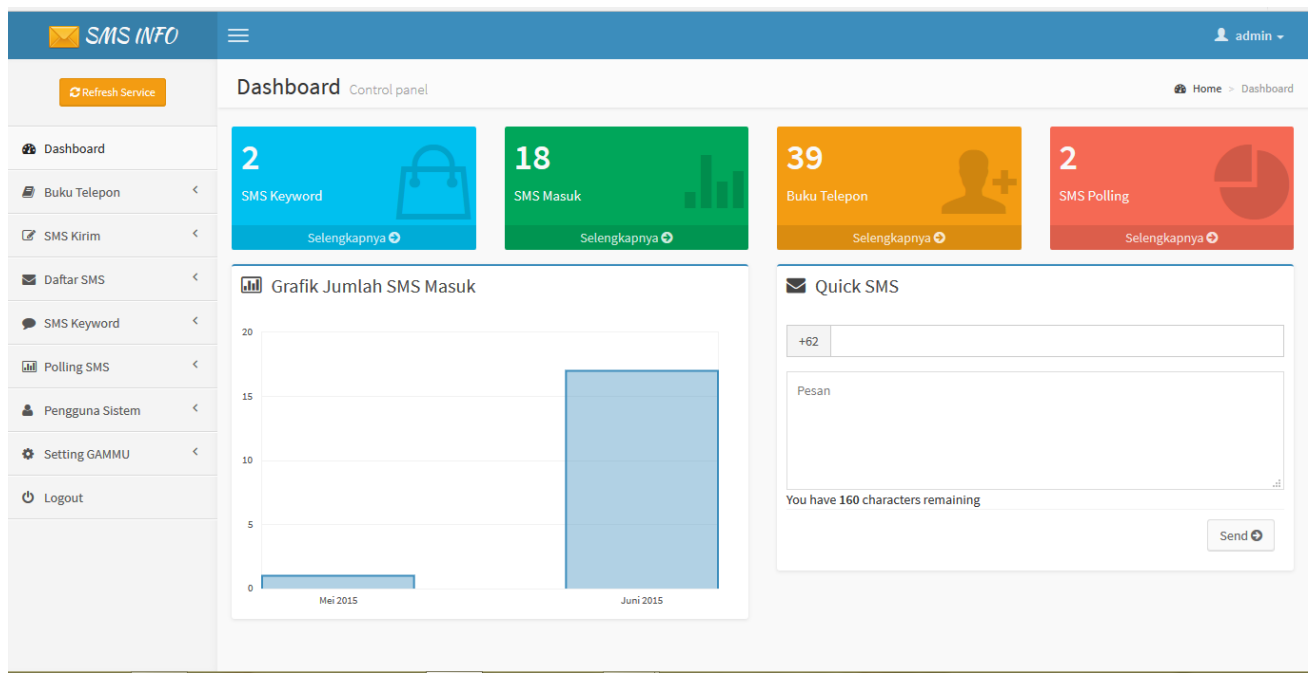

\section{Gambar 2. Halaman Beranda}

c. Menu Daftar Telepon

Pada halaman gambar 3 pengguna dapat mengelola daftar nomor telepon yang akan dikirimi SMS. Pengguna dapat menambah data dengan mengklik tombol Tambah Daftar (untuk menambah per satu data) dan Tambah Banyak (untuk menambah data secara banyak) kemudian isikan data yang diperlukan. Untuk mengubah atau menghapus daftar telepon silakan klik ikonikon yang ada disebelah kanan data.

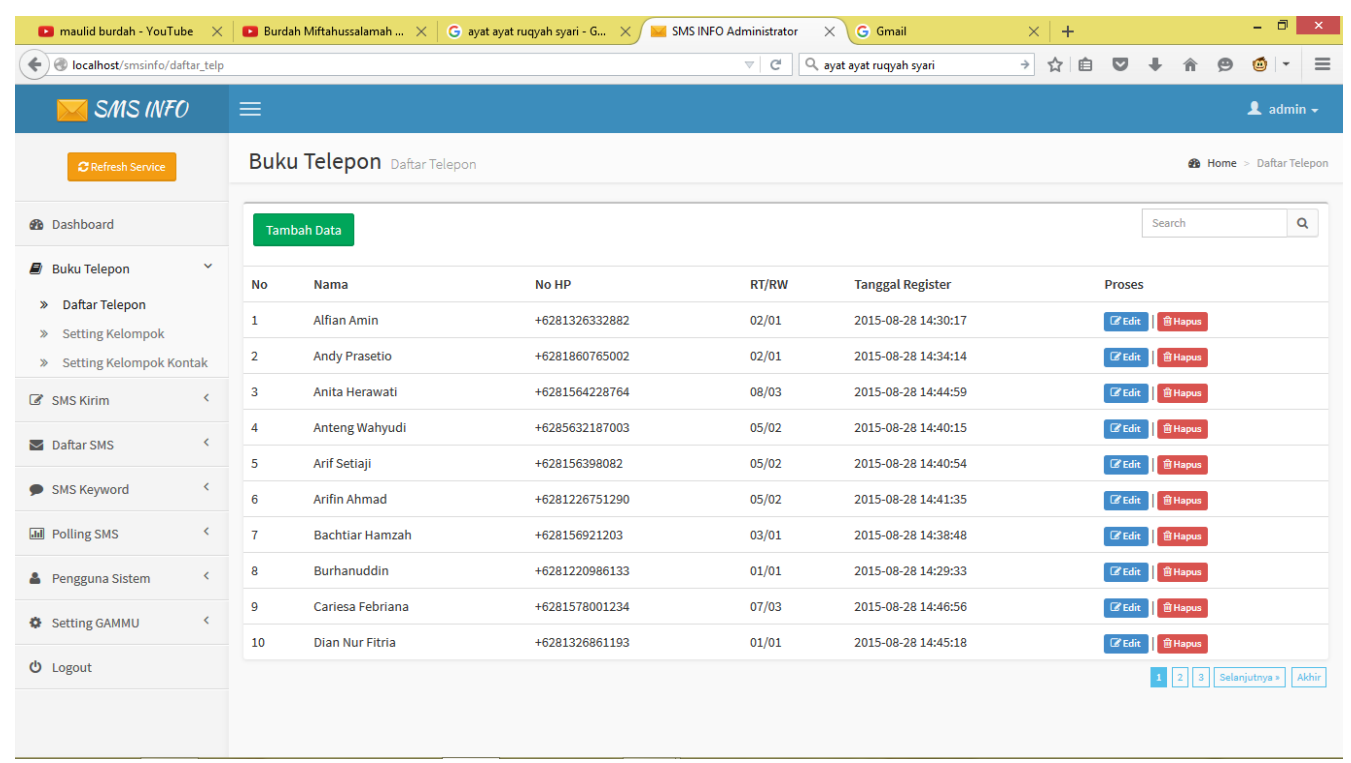

\section{Gambar 3. Halaman Menu Daftar Telepon}

d. Menu Daftar Kelompok

Menu pada gambar 4 digunakan untuk mengelola kelompok yang digunakan untuk mengelompokkan daftar telepon yang ada. Misal kelompok tani, dan lainnya. Untuk menambah data silakan klik tombol Tambah Kelompok dan kemudian isikan data yang diperlukan. Untuk menambahkan daftar telepon ke dalam kelompok silakan klik tombol centang hijau disebelah kanan data. Untuk mengubah atau menghapus data kelompok silakan klik ikon-ikon yang ada disebelah kanan data. 


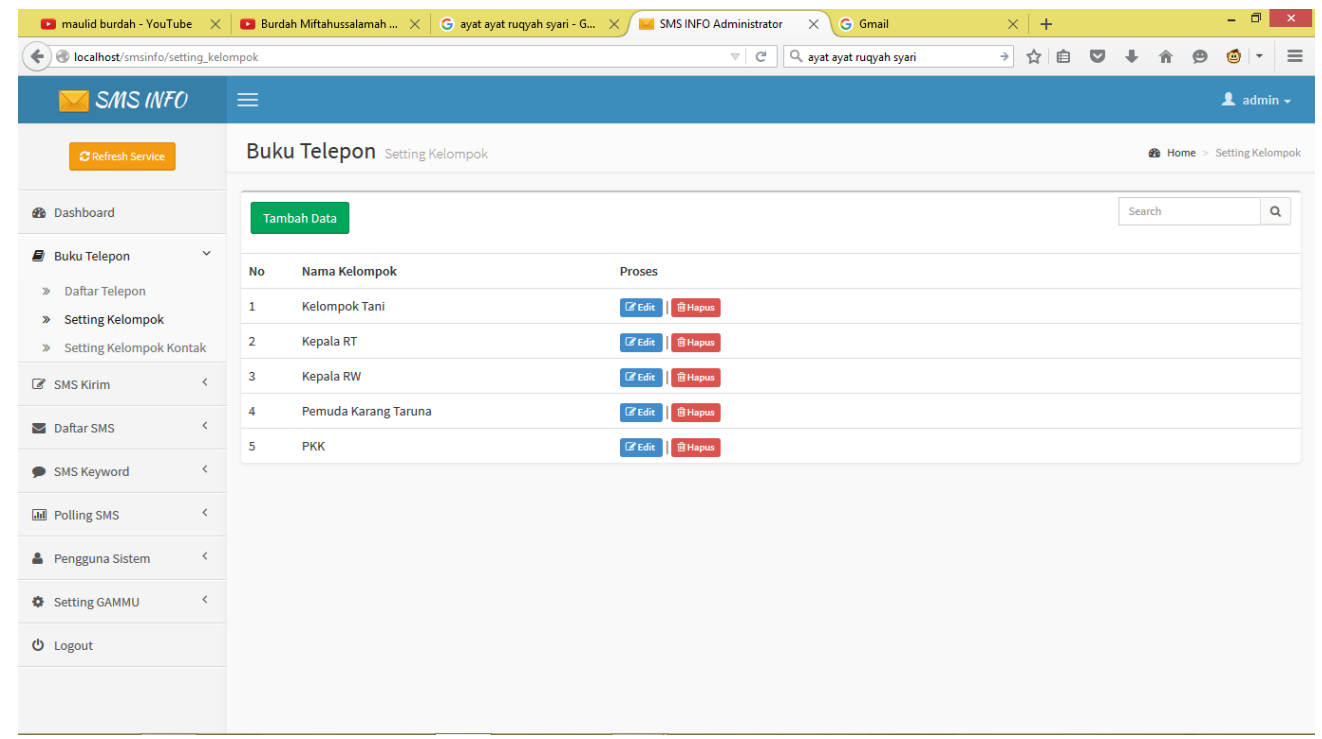

\section{Gambar 4. Halaman Menu Daftar Kelompok}

e. Menu Daftar RT/RW

Menu yang terlihat pada gambar 5 digunakan untuk mengelola daftar RT/RW yang ada di desa. Yang digunakan untuk pengisian data daftar telepon pada Menu Daftar Telepon. Untuk menambah data silakan klik tombol Tambah RT/RW, sedangkan untuk mengubah atau menghapus data silakan klik deretan ikon yang ada di sebelah kanan data.

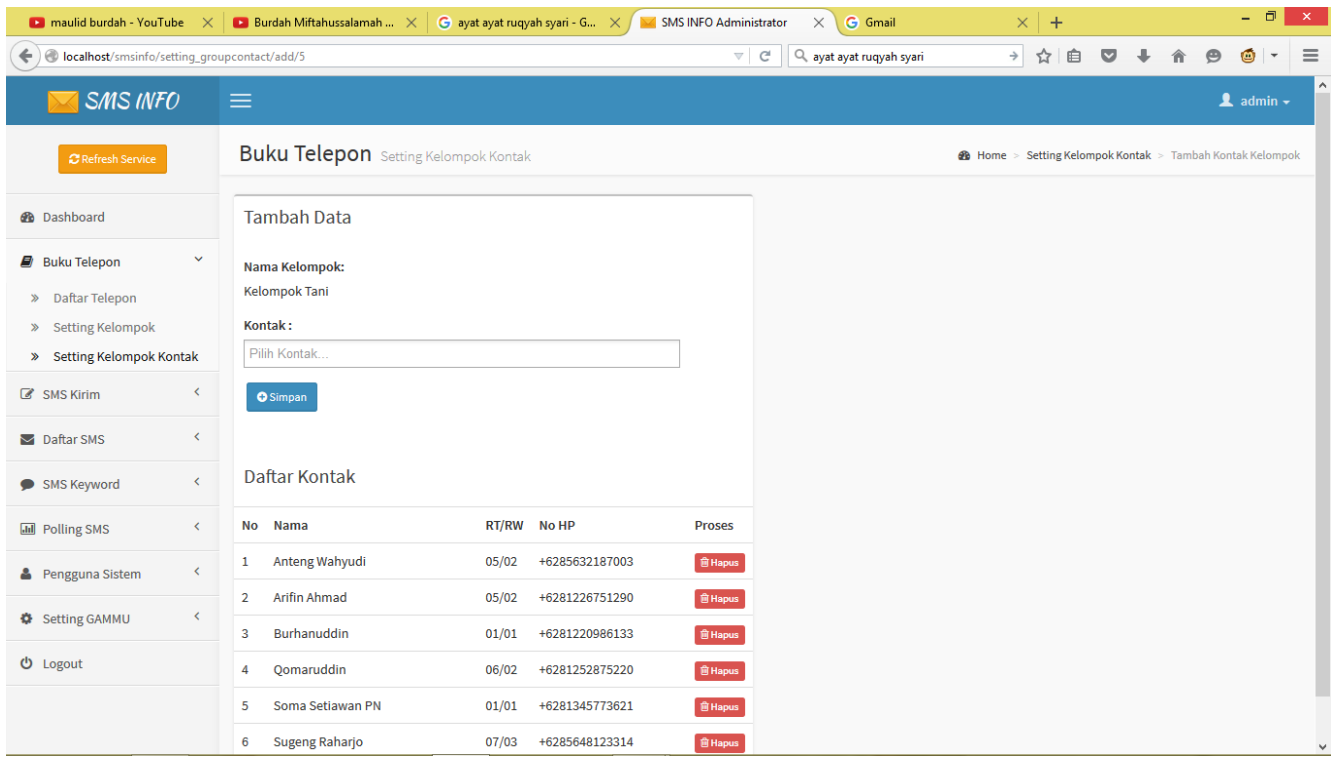

\section{Gambar 5. Halaman Menu Daftar RT/RW}

f. Menu Kirim SMS ke Nomor Tertentu

Menu pada gambar 6 digunakan untuk mengirimkan SMS ke nomor tertentu yang tidak terdaftar didalam Menu Daftar Telepon. Untuk mengirim SMS, isikan nomor telepon tujuan dan pesan yang akan dikirim. INGAT! karakter per SMS maksimal 160 karakter. Jika lebih maka akan dikirim dengan 2 kali SMS pengiriman. 


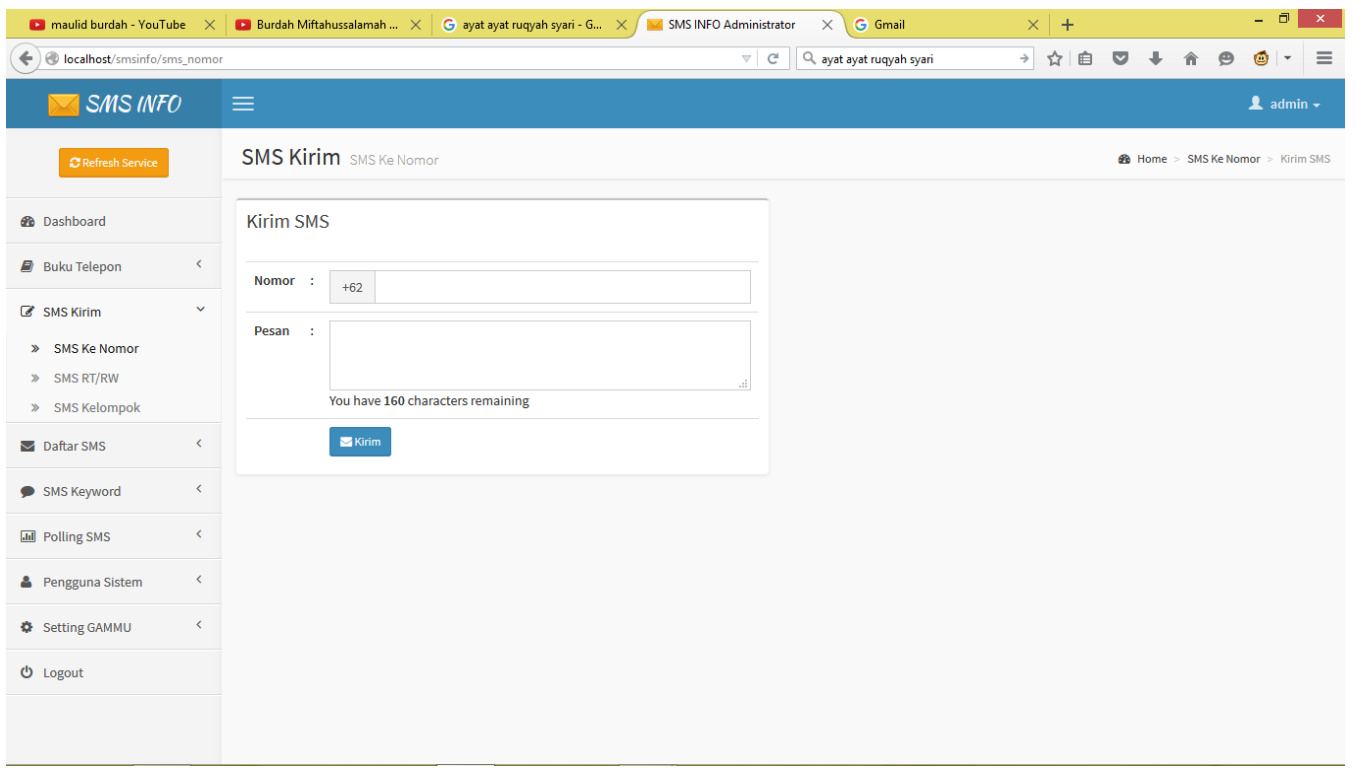

\section{Gambar 6. Halaman Menu Kirim SMS Ke Nomor Tertentu}

g. Menu Kirim SMS ke RT/RW

Menu yang terlihat pada gambar 7 digunakan untuk mengirimkan SMS ke RT/RW tertentu. Untuk mengirim SMS, pilih RT/RW tujuan yang diinginkan dan ketik pesan yang akan dikirim. INGAT! karakter per SMS maksimal 160 karakter. Jika lebih maka akan dikirim dengan 2 kali SMS pengiriman.

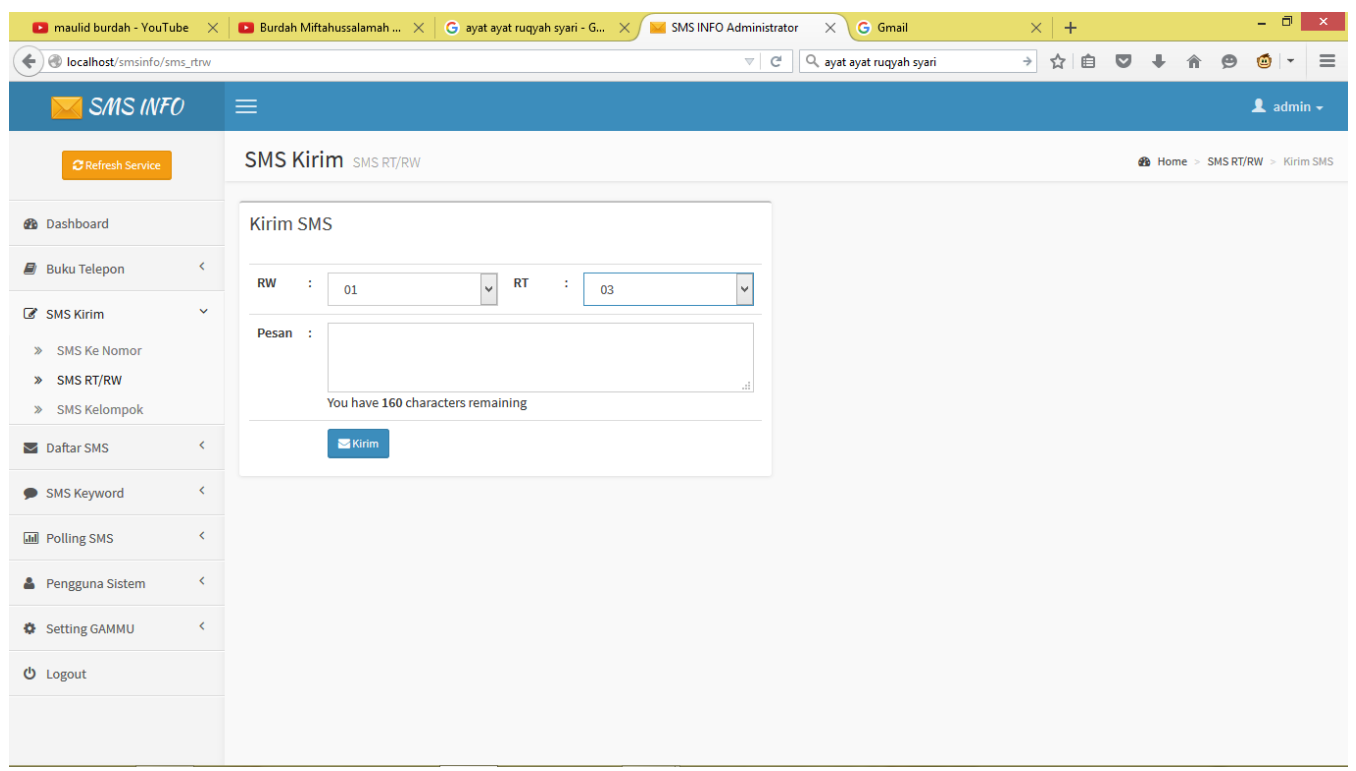

Gambar 7. Halaman Menu Kirim SMS Ke RT/RW

\section{KESIMPULAN}

Pengabdian kepada masyarakat dengan tema "Pemanfaatan Aplikasi SMS Info untuk Kemudahan Penyebaran Informasi dan Peningkatan Layanan kepada Masyarakat Desa Gondangmanis Bae Kudus" ini menghasilkan sebuah aplikasi SMS Info dan sebagai penyebaran informasi dan layanan di desa Gondangmanis. Didukung dengan pelatihan pengabdian ini bermanfaat petugas desa dan perwakilan warga dalam menggunakan dan memanfaatkan aplikasi SMS Info ini.

\section{UCAPAN TERIMA KASIH}

Terima kasih kepada Lembaga Pengabdian kepada Masyarakat Universitas Universitas Muria Kudus karena telah memfasilitasi pengabdian ini. 


\section{DAFTAR PUSTAKA}

[1] D. E. Tarigan, Membangun SMS Gateway Berbasis Web dengan CodeIgniter, Yogyakarta: Lokomedia, 2012.

[2] S. T. Setiawan Alexander, "Perancangan dan Pembuatan Sistem Layanan SMS untuk Biro Administrasi Akademik Universitas Kristen Petra," Jurnal Informatika Volume 7 Nomor 1, pp. 17 23, 2006.

[3] A. R. Wahyu Pujiyono, "Aplikasi Mobile SMS Gateway Over GPRS Untuk Mengakses Sistem Informasi," TELKOMNIKA, pp. 43-50, 2009.

[4] J. Triyono, "Pelayanan Krs On-Line Berbasis SMS, " Jurnal Teknologi, pp. 33-39, 2010.

[5] T. L. Rizkysari Meimaharani, "SMS Gateway untuk Peningkatan Penjualan Tiket Berdasarkan Framework COBIT Studi Kasus Waterboom Museum Kretek Kudus," in Seminar Nasional Ilmu Komputer, Semarang, 2012. 